\title{
Partisipasi Petani dalam Pengelolaan Hutan Rakyat di Desa Benteng Kabupaten Bogor Provinsi Jawa Barat
}

\author{
Participation of Farmers in Managing Private Forest in Benteng Village, \\ Bogor District, West Java Province
}

\author{
Indiyah Hudiyani ${ }^{1}$ \\ ${ }^{1}$ Pusat Standardisasi Kementrian Lingkungan Hidup dan Kehutanan, \\ Jakarta Pusat
}

\begin{abstract}
The existence of private forest today is an important role, especially to supply the demand of wood and to improve the environment quality. Participation of farmers is very important to developing the private forest. The farmers have been developing private forest since 2005, when The Ministry of Forestry had a program National Mobilitation of Rehabilitation in forest and land. The utilization of private forest is to be a saving for the farmers. The goals of this research was to analyzed the level participation of farmers in managing private forest and to identified the factors that correlated with the participation of farmers in managing private forest. The data were collected on Oktober-Nopember 2013 in Benteng Village, Ciampea Sub District Bogor District West Java Province using some methods: questioner list, observasion, depth interview, and documents. The data were analyzed using non parametric statistic, based on Rank-Spearman correlation test using SPSS 20 software programming. The results showed that participation of farmers in managing private forest were low and the factors that affected the participation of farmers were width of the private forest, income, motivation, forestry extension, dan the supporting from the group of farmers.
\end{abstract}

Keywords: participation of farmers, private forest

\begin{abstract}
Abstrak
Keberadaan hutan rakyat saat ini memegang peranan penting terutama untuk memenuhi kebutuhan kayu dan memperbaiki kondisi lingkungan. Partisipasi petani dalam pengelolaan hutan rakyat sangat penting untuk pengembangan hutan rakyat. Hutan rakyat dikembangkan petani Desa Benteng sejak tahun 2005 ketika ada program Gerakan Nasional Rehabilitasi Hutan dan Lahan. Hutan rakyat dimanfaatkan sebagai tabungan oleh petani Desa Benteng. Penelitian bertujuan untuk mengkaji tingkat partisipasi petani dalam pengelolaan hutan rakyat dan menemukan faktor-faktor yang berhubungan dengan partisipasi petani dalam pengelolaan hutan rakyat. Pengumpulan data dilakukan pada bulan Oktober-Nopember 2013di Desa Benteng Kecamatan Ciampea Kabupaten Bogor Provinsi Jawa Barat. Data dikumpulkan dengan menggunakan kuisioner, observasi, dan wawancara, serta studi dokumen. Data diuji dengan menggunakan uji statistik non parametrik, yaitu Uji Korelasi Rank-Spearman dengan menggunakan perangkat lunak SPSS 20. Temuan penelitian menunjukkan bahwa partisipasi petani hutan rakyat masih tergolong rendah dan faktor-faktor yang mempengaruhi partisipasi petani dalam pengelolaan hutan rakyat adalah luas lahan, pendapatan, motivasi, penyuluhan kehutanan, dan dukungan kelompok.
\end{abstract}

Kata kunci: partisipasi petani, hutan rakyat

\section{Pendahuluan}

Data dari Kemenhut (2010), laju deforestasi antara tahun 2000 - 2005 mencapai 1,08 juta hektar/ tahun. Hutan dan lahan kritis di Indonesia mencapai 77,8 juta hektar yang terdiri dari lahan sangat kritis 6,9 juta hektar, lahan kritis 23,3 juta hektar, dan agak kritis 47,6 juta hektar. Kerusakan hutan dan lahan semakin memperburuk kondisi masyarakat miskin di dalam dan sekitar hutan.

Kebutuhan kayu untuk memenuhi stok industri kehutanan dalam maupun luar negeri masih sangat kurang. Kebutuhan kayu nasional diprediksi dalam 20 tahun ini berkisar antara $50-60$ juta $\mathrm{m}^{3}$ per tahun, sedangkan kemampuan hutan alam dan hutan tanaman untuk menyediakan kayu hanya sebesar 25 30 juta $^{3}$ per tahun sehingga terjadi defisit sebesar 25 -30 juta $\mathrm{m}^{3}$ per tahun (CIFOR, 2005). Kebutuhan kayu tersebut tidak dapat mengandalkan hutan alam yang kondisinya semakin kritis dan Hutan Tanaman Industri (HTI). Hutan Rakyat (HR) saat ini menjadi salah satu alternatif untuk menjawab permasalahan defisit kayu untuk industri.

Hutanrakyatyangdikembangkandilahan-lahan milik masyarakat bertujuan selain untuk merehabilitasi hutan dan lahan kritis, juga bertujuan untuk dapat 
memenuhi permintaan pasar akan kebutuhan kayu, dan meningkatkan pendapatan masyarakat lokal sebagai pengelola. Kayu rakyat mampu memberikan kontribusi bagi penurunan defisit kebutuhan kayu yang sedang dihadapi oleh dunia kehutanan. Penggunaan bahan baku dari hutan rakyat meningkat dari tahun ke tahun. Penggunaan bahan baku dari hutan rakyat pada tahun 2011 mencapai 50\%, meningkat dari tahun sebelumnya yang berkisar $40 \%$ (BRIK, 2010). Hutan rakyat dan industri pengolahan hasilnya merupakan pilihan teknologi budidaya dan industri yang tepat bagi wilayah-wilayah yang berlahan marjinal dengan kondisi sosiobudaya tradisional (Darusman, 2002).

Berkembangnya hutan rakyat di berbagai daerah merupakan bukti bahwa pengelolaan wilayah hutan yang melibatkan masyarakat lebih bijak dibandingkan dengan pengelolaan wilayah hutan yang selama ini dilakukan oleh swasta dan juga BUMN. Kegiatan hutan rakyat akan memberikan dampak positif bagi rumah tangga pedesaan, tenaga kerja, industri, dan juga pemeliharaan terhadap lingkungan hidup. Berbagai bukti keberhasilan praktek pengelolaan hutan rakyat (hutan hak) yang dilakukan oleh masyarakat di berbagai daerah di tanah air yang telah terdokumentasi antara lain hutan rakyat di Kabupaten Wonogiri dan hutan rakyat di Kabupaten Gunung Kidul.

Salah satu hutan rakyat yang potensial untuk dikembangkan adalah hutan rakyat yang berada di Desa Benteng Kecamatan Ciampea Kabupaten Bogor Provinsi Jawa Barat. Hutan rakyat yang dikembangkan di Desa Benteng didominasi oleh tanaman jenis jeungjing atau sengon (Paraserianthes falcataria). Tanaman ini merupakan jenis tanaman hutan yang cepat tumbuh (fast growing species) sehingga dalam waktu 4-7 tahun sudah memiliki diameter yang cukup besar $(20-30 \mathrm{~cm})$. Masyarakat lebih senang menanam jeungjing karena selain dapat lebih cepat dipanen, jenis ini merupakan jenis endemik sehingga teknik silvikulturnya sudah sangat dikuasai. Selain itu, jeungjing ketika ditebang tidak langsung mati namun tonggaknya dapat tumbuh lagi menjadi tanaman baru bahkan pertumbuhannya lebih cepat (trubusan). Jenis lain yang ditanam adalah mahoni (Swietenia macrophylla). Hutan rakyat yang dikembangkan juga dicampur dengan tanaman lain sebagai tanaman di bawah tegakan yaitu kapulaga dan singkong.

Hutan rakyat dikembangkan oleh masyarakat sejak tahun 2005 yaitu ketika Departemen Kehutanan (Dephut) saat itu mengadakan Gerakan Nasional
Rehabilitasi Hutan dan Lahan (GNRHL) dengan memberikan bibit tanaman hutan kepada masyarakat. Bibit yang diberikan ditanam di lahan-lahan milik masyarakat dan masyarakat diberi bantuan berupa bantuan pemeliharaan selama 3 bulan berupa pupuk. Tanaman hutan ditanam oleh masyarakat di kebun, pinggir sawah, dan pekarangan rumah. Tanaman jenis ini digunakan oleh masyarakat sebagai suatu tabungan untuk mencukupi kebutuhan yang memerlukan dana besar seperti ketika hajatan atau keperluan untuk menyekolahkan anak.

Adanya hutan rakyat di Desa Benteng tidak hanya memberikan manfaat ekonomi, namun juga memberikan manfaat secara ekologi, dan sosial. Manfaat ekonomi yang diperoleh masyarakat adalah adanya tambahan penghasilan dari hasil penjualan kayu rakyat. Tambahanpenghasilan selain diperolehdarihasil penjualan kayu, juga diperoleh dari usaha pembibitan tanaman hutan. Dalam rangka mengembangkan hutan rakyat, masyarakat juga mulai melakukan pegembangan usaha pembibitan tanaman hutan. Bibit tanaman ini dijual kepada kepada pembeli dari luar Desa Benteng. Manfaat ekologis yang dirasakan antara lain adalah dapat mengurangi rasa panas yang terjadi pada saat musim kemarau karena tajuk pohon hutan dapat mengurangi efek panas matahari. Hal ini sesuai dengan hasil penelitian Hudiyani (2010) yang dilakukan pada hutan rakyat di Wonogiri, bahwa udara di daerah tersebut pada siang hari sangat panas namun setelah hutan rakyat banyak dikembangkan, udara menjadi tambah sejuk. Sedangkan manfaat sosial yang dirasakan adalah berkurangnya jumlah pengangguran karena banyak dari para tenaga kerja yang dipekerjakan sebagai buruh tani hutan rakyat terutama pada 3 bulan pertama penanaman. Buruh tani dipekerjakan untuk membuat lubang tanam, menanam, dan melakukan pemeliharaan hingga bulan ketiga. Selain itu, sejak hutan rakyat berkembang, banyak industri penggergajian kayu (saw mill) yang bermunculan di sekitar Kecamatan Ciampea dan Leuwiliang untuk menampung kayu hasil hutan rakyat sehingga makin banyak tenaga kerja yang diperlukan. Penjualan kayu hutan rakyat dilakukan dengan sangat sederhana, yaitu dengan menjualnya dalam keadaan berdiri. Masyarakat menjual kayu pada pembeli yang menawarkan harga tertinggi.

Partisipasi petani dalam pengelolaan kawasan hutan rakyat merupakan kunci bagi keberhasilan pengembangan hutan rakyat di Indonesia. Davis 
(1967) telah memberikan pengertian partisipasi sebagai keterlibatan mental dan emosional individu dalam situasi kelompok yang mendorong mereka untuk berkontribusi dalam upaya mencapai tujuan kelompok dan saling berbagi tanggung jawab di antara anggota-anggota kelompok. Menurut Ife (1995), agar warga masyarakat terdorong untuk mau berpartisipasi perlu diperhatikan dan dipertimbangkan beberapa persyaratan yaitu 1) anggota masyarakat akan berpartisipasi apabila isu atau kegiatan yang ditawarkan dianggap penting oleh mereka, 2) kegiatan yang ditawarkan kepada masyarakat dirasakan akan memberikan perbedaan yang nyata bagi kehidupannya, 3) bentuk partisipasi dari setiap anggota masyarakat harus dihargai dan diberi nilai tinggi, 4) tersedia peluang atau kesempatan bagi setiap angota masyarakat untuk berpartisipasi, dan 5) struktur dan proses kegiatan bukan merupakan sesuatu yang asing bagi anggota-anggota masyarakat.

Uphoff dan Cohen (Ndraha, 1990) memberikan empat tahapan partisipasi, yaitu: (1) partisipasi dalam perencanaan pembangunan, yang termasuk di dalamnya pembuatan keputusan, (2) partisipasi dalam melaksanakan operasional pembangunan, (3) partisipasi dalam menerima, memelihara, dan mengembangkan hasil pembangunan, dan (4) partisipasi dalam melakukan penilaian terhadap pembangunan. Apabila partisipasi tidak melibatkan semua tahapan tersebut, maka dikatakan bahwa partisipasi hanya bersifat parsial, dengan demikian partisipasi yang sesungguhnya harus dapat meliputi keempat tahapan tersebut.

Menurut Djamhuri(2008), partisipasi masyarakat dalam pengelolaan kawasan hutan kemasyarakatan adalah pelibatan masyarakat sebagai subyek/pelaku dalam pengelolaan hutan dengan cara memberikan kesempatan kepada masyarakat untuk dapat mengambil keputusan terkait pengelolaan seperti apa yang akan mereka lakukan. Masyarakat yang harus memutuskan jenis tanaman yang ditanam, teknik silvikultur, dan sistem bagi hasil antara negara dan masyarakat. Gupte (2004) menyatakan bahwa partisipasi warga masyarakat dalam pengelolaan hutan kemasyarakatan adalah keikutsertaan masyarakat untuk menentukan jenis pengelolaan kawasan hutan yang akan dilakukan nantinya. Masyarakat sebagai warga negara harus dilibatkan dalam setiap kebijakan terkait pengelolaan hutan karena kebijakan tersebut akan mempengaruhi kehidupan masyarakat sebagai salah satu pihak yang menerima manfaat hutan.

Menurut penelitian Diarto et al. (2012) partisipasi masyarakat dalam pengelolaan hutan mangrove dapat terbentuk dengan sendirinya karena adanya kesadaran masyarakat mengenai pentingnya hutan mangrove bagi kehidupannya. Partisipasi merupakan keterlibatan masyarakat secara aktif untuk mengelola hutan mangrovenya tanpa adanya dorongan dari pihak luar melainkan didorong oleh kebutuhan.

NamunpadasaatinihutanrakyatdiDesaBenteng mengalami penurun kuantitas dan kualitas. Penurunan kuantitas hutan rakyat ditunjukkan dengan banyaknya hutan rakyat yang kembali dikonversi menjadi lahan pertanian, yaitu untuk ditanami tanaman palawija seperti singkong, ubi jalar, dan kacang tanah sehingga luasan hutan rakyat berkurang. Penurunan kualitas hutan rakyat ditunjukkan dengan menurunnya fungsi hutan sebagai salah satu pengendali lingkungan, terutama untuk mengurangi panas pada musim kemarau. Gambaran penurunan kuantitas dan kualitas hutan rakyat di Desa Benteng dapat diteliti dari berbagai sudut pandang, salah satunya adalah dari sisi partisipasi masyarakat dalam mengelola hutan rakyat. Keterlibatan atau partisipasi masyarakat dalam pengelolaan kawasan hutan rakyat di Desa Benteng telah mengalami penurunan/degradasi sehingga diperlukan suatu penelitian mendalam untuk mengungkap dan menganalisis berbagai fakta empirik yang ikut berperan dalam mempengaruhi partisipasi warga masyarakat sehingga akan diperoleh suatu kajian yang dapat digunakan untuk meningkatkan partisipasi masyarakat dalam pengelolaan hutan rakyat.

\section{Metode Penelitian}

Rancangan penelitian yang digunakan dalam penelitian ini adalah dengan metode survei yang bersifat deskriptif korelasional untuk mendeskripsikan semua peubah yang diteliti. Penelitian ini mengamati dua peubah bebas yaitu faktor yang berasal dari dalam diri petani hutan rakyat (X1) dan faktor yang berasal dari luar diri petani hutan rakyat (X2), dan satu peubah tidak bebas yaitu partisipasi petani dalam pengelolaan hutan rakyat (Y). Lokasi penelitian adalah di Desa Benteng Kecamatan Ciampea Kabupaten Bogor Provinsi Jawa Barat. Populasi adalah semua petani hutan rakyat yang tergabung dalam Kelompok Tani Asih Desa Benteng. Penentuan sampel dilakukan dengan cara terpilih (purposive sampling) terhadap para petani yang telah memiliki lahan yang dikembangkan sebagai kawasan hutan rakyat. Jumlah sampel adalah 30 orang petani hutan rakyat yang tergabung dalam Kelompok Tani Asih Desa Benteng. 
Pengumpukan data dilakukan menggunakan kuisioner, observasi lapang, wawancara, dan studi dokumen. Kuisioner, observasi, dan wawancara dilakukan untuk memperoleh data primer, sedangkan studi dokumen dilakukan untuk memperoleh data sekunder. Data yang terkumpul kemudian dianalisis. Pengolahan dan analisis data menggunakan statistik deskriptif dan juga statistik inferensial uji korelasi Rank-Spearman dengan menggunakan software SPSS 20.

\section{Hasil dan Pembahasan}

\section{Sejarah Hutan Rakyat Desa Benteng}

Hutan rakyat yang ada di Desa Benteng mulai dibangun pada tahun 2005, yaitu saat Departemen Kehutanan (Dephut) mencanangkan program Gerakan Nasional Rehabilitasi Hutan dan Lahan. Dephut memberikan bantuan berupa bibit tanaman hutan kepada masyarakat untuk ditanam di lahan mereka masing-masing. Jenis tanaman yang diberikan adalah sengon (jeungjing) dan mahoni. Jeungjing merupakan tanaman jenis cepat tumbuh (fast growing species) sehingga dalam waktu pendek 4-7 tahun sudah dapat dipanen. Masyarakat Desa Benteng sudah sejak dulu mengenal jeungjing karena jeungjing merupakan salah satu jenis tanaman hutan yang secara alami tumbuh di sekitar Desa Benteng sehingga masyarakat umum sudah menguasai teknik budidaya tanaman jeungjing. Untuk kegiatan penanaman ini, Dephut juga memberikan masyarakat upah untuk menanam bibit sekaligus pemberian pupuk untuk kegiatan pemeliharaan bibit selama 3 bulan.

Masyarakat menanam tanaman kayu di lahan-lahan pekarangan, kebun, dan bahkan ada yang mengeringkan sawahnya agar bisa ditanami tanaman kayu. Pada saat itu di Jawa Barat sedang ada program sengonisasi dimana setipa lahan kosong ditanami dengan tanaman sengon atau yang di wilayah Jawa Barat lebih dikenal sebagai tanaman jeungjing. Masyarakat umum lebih menyukai tanaman jeungjing dibandingkan mahoni karena lebih cepat besar sehingga lebih cepat panen. Tanaman sengon ditanam di hampir seluruh hamparan lahan dengan diselingi sedikit mahoni. Untuk memanfaatkan lahan di bawah tegakan, masyarakat menanam tanaman singkong atau kapulaga. Tanaman singkong akan terus ditanam ketika tanaman hutan masih muda (1-2 tahun) karena masih banyak cahaya matahari yang sampai ke lantai hutan sehingga singkong masih bisa tumbuh dengan baik. Perkembangan kawasan hutan rakyat di Indonesia semakin maju pesat sehingga kebutuhan bibit semakin hari juga semakin besar. Masyarakat Desa Benteng dengan dorongan dari tokoh masyarakat mulai mencoba untuk membuat persemaian bibit tanaman hutan. Jenis tanaman yang pertama disemaikan adalah jeungjing dikarenakan benihnya banyak terdapat di Desa Benteng dan teknik pembuatan bibit jeunghjing sudah sangat mereka kuasai.

\section{Pengelolaan Hutan Rakyat Desa Benteng}

Hutan rakyat yang dikembangkan di Desa Benteng dilakukan secara individu. Setiap kegiatan mulai dari pengadaan bibit hingga pemananen dilakukan oleh individu. Tidak seperti hasil penelitian Hudiyani (2010) di Kelurahan Selopuro Kecamatan Batuwarno Kabupaten Wonogiri Provinsi Jawa Tengah, pengelolaan hutan rakyat pada tahap awal yakni penanaman dilakukan secara berkelompok, yaitu pada kegiatan penanaman semua anggota kelompok turut berpartisipasi dalam proses penanaman tanaman hutan di suatu lahan. Kegiatan penanaman dilakukan secara bergilir dengan cara diundi sehingga selain meringankan pemilik hutan juga dapat bermanfaat untuk meningkatkan rasa kekeluargaan diantara petani hutan rakyat.

Bibit yang ditanam biasanya berasal dari cabutan anakan yang banyak tumbuh di sekitar pohon induk. Hal ini dimungkinkan karena sebelum hutan rakyat dibangun, Desa Benteng juga banyak ditumbuhi tanaman jeungjing. Petani menanam tanaman hutan dengan jarak tanam yaitu sekitar $2 \times 2 \mathrm{~m}$. Tanaman singkong atau kapulaga ditanam di sela-sela tanaman kayu. Ketika cahaya matahari sudah sulit menembus lantai hutan karena kerapatan tajuk yang sudah rapat maka tanaman pertanian sudah tidak dapat ditanam.

Kegiatan pemeliharaan dilaksanakan hingga tanaman berumur 1 tahun yaitu dengan pemupukan ketika bibit ditanam, kemudain dilanjutkan dengan pupuk lanjutan setiap bulan hingga bibit berumur 3 bulan. Kegiatan pemeliharaan tanaman lainnya adalah penyulaman yaitu mengganti bibit yang mati dengan bibit yang bagus. Pupuk yang digunakan adalah pupuk kandang dicampur dengan pupuk kimia. Pupuk kandang dapat dipenuhi sendiri oleh masyarakat Desa Benteng. Setelah tanaman berusia di atas 1 tahun, tanaman tidak 
Tabel 1 Deskripsi Faktor Internal Petani Hutan Rakyat di Desa Benteng Kecamatan Ciampea Kabupaten Bogor

\begin{tabular}{|c|c|c|c|}
\hline \multirow{2}{*}{ Faktor internal (X1) } & \multirow{2}{*}{ Kategori } & \multicolumn{2}{|c|}{ Jumlah } \\
\hline & & $\mathbf{n}$ & $\%$ \\
\hline \multirow[t]{3}{*}{ Umur } & Muda (<41 tahun) & 13 & 43,33 \\
\hline & Cukup tua (41 - 56 tahun) & 10 & 33,33 \\
\hline & Tua ( $>57$ tahun $)$ & 7 & 23,33 \\
\hline Total & & 30 & 100,00 \\
\hline \multirow[t]{3}{*}{ Pendidikan Formal } & Rendah $(<9$ tahun $)$ & 15 & 50,00 \\
\hline & Sedang (10 - 12 tahun) & 13 & 43,33 \\
\hline & Tinggi ( $>12$ tahun) & 2 & 6.67 \\
\hline Total & & 30 & 100,00 \\
\hline \multirow[t]{3}{*}{ Pendidikan Non Formal } & Rendah $(<29$ jam $)$ & 14 & 46,67 \\
\hline & Sedang (30 - 59 jam) & 8 & 26,67 \\
\hline & Tinggi (> 60 jam $)$ & 8 & 26,67 \\
\hline Total & & 30 & 100,00 \\
\hline \multirow[t]{3}{*}{ Pengalaman Bertani } & Rendah $(<5$ tahun $)$ & 0 & 0,00 \\
\hline & Sedang (5 - 10 tahun) & 30 & 100,00 \\
\hline & Tinggi ( $>10$ tahun) & 0 & 0,00 \\
\hline Total & & 30 & 100,00 \\
\hline \multirow{3}{*}{ Luas Lahan } & Sempit (<0,7 ha) & 24 & 80,00 \\
\hline & Sedang (0,7 - 1,3 ha) & 4 & 13,33 \\
\hline & Luas ( $>1.3$ ha) & 2 & 6,67 \\
\hline Total & & 30 & 100,00 \\
\hline \multirow[t]{3}{*}{ Pendapatan } & Rendah $(<1.500 .000$ rupiah $)$ & 18 & 60,00 \\
\hline & Sedang $(1.500 .000-2.250 .000)$ & 9 & 30,00 \\
\hline & Tinggi (> 2.250.000 rupiah) & 3 & 10,00 \\
\hline Total & & 30 & 100,00 \\
\hline \multirow[t]{3}{*}{ Jumlah tanggungan keluarga } & Sedikit $(<3$ orang) & 8 & 0,100 \\
\hline & Sedang ( 3 - 5 orang) & 17 & 56,67 \\
\hline & Banyak ( $>5$ orang) & 5 & 16,67 \\
\hline Total & & 30 & 100,00 \\
\hline \multirow[t]{3}{*}{ Motivasi } & Rendah $(<11,67)$ & 21 & 70,00 \\
\hline & Sedang $(11,67-16.34)$ & 6 & 20,00 \\
\hline & Tinggi $(>16,34)$ & 3 & 10,00 \\
\hline Total & & 30 & 100,00 \\
\hline
\end{tabular}

perlu dipupuk lagi namun pembersihan gulma masih tetap dilakukan. Pemangkasan hanya dilakukan ketika tanaman mencapai tinggi 1,5 meter karena pemangkasan (prunning) yang dilakukan dengan cara konvensional yaitu dengan gergaji atau golok.

Masyarakat Desa Benteng tidak melakukan kegiatan penjarangan, yaitu penebangan tanaman yang bersifat inferior dibandingkan dengan tanaman lainnya. Penjarangan bertujuan untuk dapat memperbesar ruang tumbuh dan pemenuhan kebutuhan akan sinar matahari.
Penebangan yang dilakukan masyarakat Desa Benteng hanya penebangan pemanenan. Pemanenan dilakukan dengan cara memanen kayu dalam posisi masih tegak. Pedagang akan datang ke lokasi-lokasi hutan rakyat dimana pohonnya kemudian akan dijual.

\section{Faktor Internal}

Faktor internal dari para petani meliputi umur, pendidikan formal, pendidikan non-formal, pengalaman 
Tabel 2 Deskripsi Faktor Eksternal Petani Hutan Rakyat di Desa Benteng Kecamatan Ciampea Kabupaten Bogor Provinsi Jawa Barat

\begin{tabular}{llrr}
\hline \multirow{2}{*}{ Faktor Eksternal (X2) } & \multicolumn{1}{c}{ Kategori } & \multicolumn{2}{c}{ Jumlah } \\
& & n & \% \\
\hline Penyuluhan Kehutanan & Rendah $(<10)$ & 12 & 40,00 \\
& Sedang $(10-14)$ & 12 & 40,00 \\
& Tinggi $(>14)$ & 6 & 20,00 \\
\hline Total & & 30 & 100,00 \\
\hline Ketersediaan Informasi & Rendah $(<10)$ & 2 & 6,67 \\
& Sedang $(10-14)$ & 16 & 53,33 \\
& Tinggi $(>14)$ & 12 & 40,00 \\
\hline Total & & 30 & 100,00 \\
\hline Dukungan Kelompok & Rendah $(11,67)$ & 7 & 23,33 \\
& Sedang $(11,67-13.34)$ & 0 & 0,00 \\
& Tinggi $(>13,34)$ & 23 & 76,67 \\
\hline Total & & 30 & 100,00 \\
\hline
\end{tabular}

berusaha tani, luas lahan usaha tani, pendapatan, jumlah tanggungan keluarga, dan motivasi berusaha. Deskripsi faktor internal petani selengkapnya disajikan pada Tabel 3. Petani yang terlibat dalam kegiatan pengelolaan hutan rakyat sebagian besar berusia muda yaitu 13 orang atau 43,33\% (Tabel 1). Terlihat lebih banyak responden yang masuk pada usia produktif. Hal ini terjadi karena sebagian besar petani berusia tua telah menyerahkan pengelolaan lahannya kepada anaknya. Petani berumur tua lebih banyak melakukan kegiatan pemeliharaan ternak yang dianggap tidak terlalu berat karena hanya memberi makan pada pagi dan sore hari.

Selain itu, para petani berusia muda memiliki kebutuhan yang lebih banyak dibandingkan dengan petani berusia tua karena petani muda memiliki anakanak yang masih membutuhkan biaya untuk melanjutkan sekolah sehingga petani muda memiliki keinginan untuk memperoleh tambahan penghasilan yaitu dengan cara menanam tanaman hutan di lahannya. Selama ini tanaman kayu digunakan oleh petani sebagai tabungan untuk memenuhi kebutuhan yang besar seperti biaya sekolah atau hajatan. Petani berusia tua biasanya sudah tidak memiliki anak yang masih bersekolah. Pendidikan formal petani hutan rakyat sebagian besar masih rendah yaitu di bawah SLTP sebanyak 15 orang atau 50\%. Petani yang berpendidikan rendah didominasi oleh petani hutan rakyat yang berumur tua, sedangkan petani yang berumur muda memiliki tingkat pendidikan formal yang lebih tinggi. Rendahnya tingkat pendidikan petani berkorelasi dengan umur petani, yang semakin tua usia petani maka akan semakin rendah tingkat pendidikan formalnya.

Rendahnya tingkat pendidikan petani dapat menjadi penyebab dari rendahnya kemampuan petani dalam pengelolaan hutan rakyat yang dapat menjadi penghambat bagi peningkatan produksi usahatani hutan rakyat, karena taraf pendidikan yang rendah dapat menimbulkan berbagai dampak yang sifatnya mengurangi respons petani terhadap usaha untuk mengembangkan usahataninya, antara lain tidak akan berani mengadakan perubahan dan kurang mampu menyerap informasi. Pendidikan merupakan salah satu faktor yang berpengaruh bagi perkembangan kualitas pribadi dan kepribadian seseorang dan juga bagi kemajuan suatu masyarakat. Melalui pendidikan orang akan mampu untuk memikirkan dan berusaha untuk meningkatkan taraf hidupnya.

Pendidikan non-formal petani berkisar antara 0-88 jam dengan rata-rata 34,13 . Tingkat pendidikan non formal petani didominasi oleh tingkat pendidikan non formal rendah yaitu 14 orang (46,67\%). Sebagian besar petani tua tidak memperoleh pendidikan non formal yang dapat menunjang kegiatannya dalam melakukan pengelolaan hutan rakyat. Hal ini sesuai dengan penelitian Azis (1995) yang menyimpulkan bahwa tingkat pendidikan berhubungan dengan pengetahuan petani tentang perladangan berpindah, dengan demikian bila dihubungkan dengan kegiatan 
Jurnal Penyuluhan, September 2013 Vol. 9 No. 2

Tabel 3 Deskripsi Partisipasi Petani Hutan Rakyat Desa Benteng dalam Pengelolaan Hutan Rakyat

\begin{tabular}{llrr}
\hline \multicolumn{1}{c}{ Partisipasi (Y1) } & \multicolumn{1}{c}{ Kategori } & \multicolumn{2}{c}{ Jumlah } \\
& \multicolumn{1}{c}{ n } & \% \\
\hline Partisipasi dalam Perencanaan & & 30 & 100,00 \\
Partisipasi dalam Pelaksanaan & Rendah $(<13,33)$ & 20 & 66,67 \\
& Sedang $(13,33-18,66)$ & 8 & 26,67 \\
& Tinggi $>18,66)$ & 2 & 6,67 \\
Partisipasi dalam Memanfaatkan Hasil & Rendah $(<10)$ & 15 & 50,00 \\
& Sedang $(10-14)$ & 11 & 36,67 \\
& Tinggi $(>14)$ & 4 & 13,33 \\
Partisipasi dalam Evaluasi & Rendah $(<10,67)$ & 29 & 96,67 \\
& Sedang $(10,67-13,34)$ & 0 & 0,00 \\
& Tinggi $(>13,34)$ & 1 & 3,33 \\
\hline
\end{tabular}

pengelolaan hutan, maka pendidikan yang pernah dijalani oleh petani baik formal dan non formal akan memberikan kontribusi terhadap pengetahuan, sikap, dan juga keterampilan petani dalam pengelolaan hutan tersebut.

Keseluruhan responden penelitian ini memiliki pengalaman berusaha tani yang sama karena cikal bakal pengembangan hutan rakyat dilakukan pada tahun 2005 ketika ada proyek GNRHL di Desa Benteng. Petani tertarik untuk membangun hutan rakyat pada saat pemerintah gencar melakukan kegiatan penyuluhan terkait hutan rakyat pada saat itu. Luas lahan yang diusahakan oleh petani sebagai hutan rakyat tergolong sempit yaitu kurang dari 0,6 ha. Sebagian besar petani (24 orang atau $80 \%$ ) memiliki luasan hutan rakyat yang sangat sempit. Hal ini disebabkan banyak petani yang sudah mengganti tanaman hutannya dengan tanaman pertanian kembali yaitu singkong karena merasa tanaman kayu memberikan keuntungan yang relatif lama karena daurnya yang panjang, sedangkan kebutuhan untuk hidup sehari-hari mengharuskan mereka untuk memperoleh penghasilan dalam jangka waktu yang pendek.

Tingkat pendapatan petani hutan rakyat di Desa Benteng termasuk kategori rendah yaitu di bawah Rp 1.500.000,- sebanyak 18 orang atau $60 \%$. Sumber pendapatan yang diperoleh bukan hanya berasal dari hutan rakyat namun juga berasal dari sawah, ternak, dan buruh tani. Sebagian besar penduduk Desa Benteng merupakan buruh migran sehingga jumlah pendapatan ini juga bersumber dari kiriman keluarga yang bekerja sebagai seorang buruh migran. Pendapatan petani yang diperoleh dari hutan rakyat masih sulit dihitung besarannya karena hasil dari hutan rakyat tidak digunakan sebagai penghasilan utama melainkan sebagai tabungan yang akan digunakan ketika petani menghadapi kebutuhan bernilai besar misalnya untuk menyekolahkan anak atau hajatan. Hal ini disebabkan karena petani hutan rakyat di Desa Benteng tidak memanfaatkan bagian lain dari tanaman kayu. Tidak seperti pada penelitian Djamhuri (2002) yang dilakukan di Kabupaten Gunung Kidul dimana petani memanfaatkan ranting dan daun pohon jati untuk dijual dan hasilnya digunakan untuk menambah pemenuhan kebutuhan sehari-hari.

Jumlah tanggungan keluarga petani Desa Benteng didominasi oleh para petani dengan jumlah tanggungan anggota keluarga termasuk kategori sedang dengan jumlah responden 17 orang atau 56,67\%. Semakin tinggi jumlah tanggungan keluarga maka akan semakin berat beban hidup untuk memenuhi kebutuhan sehari-hari seluruh anggota keluarga. Kondisi inilah mendorong petani melakukan diversifikasi usaha yaitu pertanian sawah, hutan rakyat, ternak, dan bahkan beberapa petani bekerja sebagai buruh di sela - sela kegiatan pertaniannya. Jumlah tanggungan keluarga yang cukup banyak dikarenakan tingkat kekerabatan yang masih tinggi di Desa Benteng sehingga tanggungan keluarga bukan hanya terdiri dari keluarga inti melainkan juga di luar keluarga inti.

Sebagian besar responden memiliki motovasi yang rendah untuk mengelola kawasan hutan rakyat yaitu 21 orang $(70 \%)$. Rendahnya motivasi petani disebabkan karena belum munculnya kesadaran dari diri sendiri untuk mengelola hutan rakyat. Para petani hutan rakyat di Desa Benteng mengelola hutan rakyat disebabkan karena 
Jurnal Penyuluhan, September 2013 Vol. 9 No. 2

Tabel 4 Hubungan Faktor Internal dengan Partisipasi Petani dalam Pengelolaan Hutan Rakyat

\begin{tabular}{|c|c|c|c|c|}
\hline \multirow{2}{*}{ No } & \multirow{2}{*}{ Faktor internal } & \multicolumn{3}{|c|}{ Partisipasi petani } \\
\hline & & Pelaksanaan & Pemanfaatan & Evaluasi \\
\hline 1 & Umur & 0,236 & 0,328 & 0,204 \\
\hline 2 & Pendidikan formal & $-0,007$ & $-0,109$ & 0,149 \\
\hline 3 & Pendidikan non formal & $-0,202$ & $-0,241$ & $-0,130$ \\
\hline 4 & Pengalaman & 0,130 & 0,177 & 0,034 \\
\hline 5 & Luas lahan & $0,767 * *$ & $0,899^{* *}$ & 0,330 \\
\hline 6 & Pendapatan & $0,699^{* *}$ & $0,650^{* *}$ & 0,290 \\
\hline 7 & Jumlah tanggungan keluarga & 0,053 & 0,044 & $-0,066$ \\
\hline 8 & Motivasi & $0,679 * *$ & $0,793 * *$ & 0,360 \\
\hline
\end{tabular}

Keterangan: **Korelasi sangat nyata pada taraf $\alpha \leq 1 \%$

adanya dorongan dari pemerintah terutama pemberian bibit tanaman hutan dan biaya pemeliharaan hingga bibit berumur 3 bulan. Ketika pemberian bantuan tersebut berhenti maka petani mulai kembali ke pola tani lama yaitu pertanian pangan. Hal ini disebabkan karena petani merasa bahwa hasil yang diperoleh dari hutan rakyat sangat lama sedangkan mereka harus tetap memenuhi kebutuhan rutinnya setiap hari. Meskipun demikian, ada beberapa petani yang memiliki dorongan dari diri sendiri untuk mengembangkan hutan rakyat di Desa Benteng. Pemberian bantuan dari pemerintah berupa bibit dan juga pengetahuan dan juga ketrampilan merupakan suatu dorongan awal untuk mengembangkan hutan rakyat. Selanjutnya mereka merasakan adanya manfaat yang dirasakan dari adanya hutan rakyat tersebut antara lain adanya tambahan penghasilan dan juga perbaikan kondisi lingkungan dalam hal ini mengurangi cuaca panas pada musim kemarau.

\section{Faktor Eksternal}

Faktor eksternal adalah faktor yang berasal dari luar diri seseorang/individu dan merupakan faktor penting untuk mengetahui upaya seseorang dalam melakukan suatu aktivitas atau usaha. Faktor eksternal yang diteliti adalah penyuluhan bidang kehutanan, ketersediaan informasi mengenai kawasan hutan rakyat, dan dukungan kelompok tani. Deskripsi faktor eksternal petani hutan rakyat disajikan pada Tabel 2 .

Rata-rata skor indikator penyuluhan kehutanan adalah 10,73 dengan kisaran 6-18. Kegiatan penyuluhan yang dilaksanakan selama ini berada pada kategori rendah (40\%) dan sedang (40\%). Penyuluhan yang dilakukan saat ini jarang frekuensinya, tidak seperti pada tahun 2005 ketika program GNRHL dicanangkan. Penyuluh biasanya hadir pada saat pertemuan rutin kelompok yaitu setiap bulan pada Minggu II. Materi penyuluhan sejauh ini cukup mudah untuk dipahami oleh petani karena penyuluh menyampaikannya dalam bahasa lokal yaitu bahasa Sunda. Materi penyuluhan biasanya disampaikan secara proporsional antara teori dan praktek. Namun demikian, tidak setiap pertemuan kelompok dihadiri oleh penyuluh kehutanan. Pada saat penyuluh tidak hadir dalam pertemuan kelompok, biasanya materi penyuluhan diisi oleh sesama petani baik pengurus maupun anggota yang telah mengikuti pelatihan baik terkait pengelolaan hutan rakyat maupun materi lainnya. Jarangnya frekuensi kegiatan penyuluhan yang dilakukan oleh penyuluh kehutanan disebabkan antara lain jumlah penyuluh kehutanan hanya seorang dengan cakupan wilayah 3 kecamatan dengan lokasi yang cukup berjauhan.

Ketersediaan informasi terkait hutan rakyat menurut responden termasuk dalam kategori sedang yaitu 53,33\%. Ketersediaan informasi yang dimaksud adalah kemudahan petani untuk memperoleh informasi terkait hutan rakyat cukup mudah baik melalui kelompok, penyuluh, media cetak maupun elektronik, maupun dari sesama petani. Jumlah informasi yang diperoleh petani terkait hutan rakyat juga cukup banyak, berupa informasi mengenai budidaya tanaman hutan mulai dari pembibitan hingga pengendalian hama dan penyakit. Namun demikian, terdapat beberapa informasi yang belum diperoleh petani hingga saat ini yakni mengenai semacam penyakit yang sering menyerang tanaman sengon ketika tanaman sudah berumur 3-4 tahun. Penyakit ini merupakan penyakit yang baru ditemui oleh petani dan hingga saat ini belum ada informasi yang dapat 
Jurnal Penyuluhan, September 2013 Vol. 9 No. 2

Tabel 5 Hubungan Faktor Eksternal dengan Partisipasi Petani dalam Pengelolaan Hutan Rakyat

\begin{tabular}{clccc}
\hline \multirow{2}{*}{ No } & \multirow{2}{*}{ Faktor eksternal } & \multicolumn{3}{c}{ Partisipasi petani } \\
& & Pelaksanaan & Pemanfaatan & Evaluasi \\
\hline 1 & Penyuluhan kehutanan & 0,114 & $0,406^{*}$ & 0,069 \\
2 & Ketersediaan informasi & $-0,166$ & $-0,032$ & 0,218 \\
3 & Dukungan kelompok & 0,231 & $0,396^{*}$ & 0,102 \\
\hline
\end{tabular}

Keterangan: Korelasi nyata pada taraf $\alpha \leq 5 \%$

diperoleh petani untuk membasmi penyakit tersebut.

Kelompok tani hutan merupakan lembaga yang sangat menunjang petani dalam pengelolaan hutan rakyat di Desa Benteng. Petani hutan menyatakan bahwa dukungan kelompok terhadap pengelolaan hutan rakyat yang dilakukannya tinggi (76,67\%). Kelompok merupakan wahana bagi para petani untuk dapat saling bertukar pengalaman satu sama lain sehingga terjadi interaksi yang intensif diantara sesama petani. Melalui kelompok pulalah berbagai informasi dapat diterima petani hutan rakyat untuk meningkatkan usahanya. Kegiatan penyuluhan dilakukan pada saat dilakukan pertemuan rutin kelompok sehingga melalui kelompok maka petani dapat meningkatkan pengetahuan serta keterampilannya. Setiap kelompok memiliki norma dan nilai yang sangat dijunjung tinggi oleh anggotanya. Kelompok mempunyai pengaruh terhadap perilaku anggota-anggotanya, yang meliputi pengaruh terhadap persepsi, pengaruh terhadap sikap, dan pengaruh terhadap tindakan individu (Santosa, 1992). Dengan demikian, nilai, norma, interaksi dalam kelompok, kepemimpinan, dan dinamika kelompok memberikan kontribusi tersendiri terhadap bentuk pola interaksi anggotanya ketika berinteraksi dengan lingkungan di luar kelompok. Dalam konteks pengelolaan hutan, perilaku petani dalam mengelola hutan juga akan dipengaruhi oleh norma dan nilai kelompok di mana ia menjadi anggota.

\section{Partisipasi Petani}

Partisipasimerupakansuatubentukketerlibatan langsung petani dalam kegiatan pengelolaan hutan rakyat. Partisipasi yang diamati dalam penelitian ini mencakup partisipasi dalam perencaan hutan rakyat, partisipasi dalam pengelolaan hutan rakyat, partisipasi dalam menikmati hasil hutan rakyat, dan partisipasi dalam evaluasi pengelolaan hutan rakyat. Deskripsi lengkap mengenai tingkat partisipasi petani dalam pengelolaan hutan rakyat disajikan dalam Tabel 3 . Tingkat partisipasi petani hutan rakyat tergolong rendah, yang ditunjukkan oleh rendahnya 3 tahapan pada partisipasi yaitu partisipasi dalam pelaksanaan, partisipasi dalam pemanfaatan hasil, dan partisipasi dalam evaluasi pengelolaan hutan rakyat. Partisipasi merupakan keterlibatan secara aktif masyarakat dalam suatu kegiatan atau program pembangunan. Inisiatif kegiatan atau program dapat berasal dari luar masyarakat atau muncul dari dalam masyarakat itu sendiri. Sardjono (2004) mengemukakan bahwa partisipasi warga masyarakat merupakan suatu proses dimana masyarakat dilibatkan pada setiap tahap situasi yang dapat berpengaruh terhadap kehidupan mereka. Maksud dari partisipasi adalah untuk mendorong kemandirian masyarakat sehingga tercapai pembangunan yang bersifat berkelanjutan (sustainable development).

Rendahnya partisipasipetani dapat disebabkan oleh beberapa hal yaitu: hutan rakyat belum dianggap sebagai kegiatan yang penting bagi petani karena tidak terdapat perbedaan yang cukup nyata bagi kehidupan petani dan keluarganya. Selain itu, dukungan dari para pihak terhadap pengembangan hutan rakyat masih belum memadai sehingga petani merasa harus berjuang sendiri untuk mengembangkan hutan rakyat.

\section{Hubungan Faktor Internal dengan Partisipasi Petani dalam Pengelolaan Hutan Rakyat}

Faktor internal adalah faktor dari dalam diri petani yang berhubungan dengan partisipasi petani dalam pengelolaan hutan rakyat di Desa Benteng. Berdasarkan Tabel 4 terlihat bahwa umur responden tidak berkorelasi nyata pada taraf $\alpha \leq 5 \%$ dengan partisipasi petani dalam pengelolaan hutan rakyat. Hal ini menunjukkan bahwa umur petani ternyata tidak mempengaruhi tingkat partisipasi petani dalam pengelolaan hutan rakyat. Rogers (1995) menyatakan bahwa umur tidak 
berkorelasi dengan kecepatan mengadopsi suatu inovasi. Pengembangan hutan rakyat merupakan sebuah inovasi bagi petani di Desa Benteng yang dikenalkan oleh Dephut dalam program GNRHL pada tahun 2005. Sebelumnya para petani hanya mengusahakan tanaman pangan saja sebagai komoditas pertaniannya namun dengan adanya program ini maka petani mulai tertarik untuk menanam tanaman hutan dilahan yang dimiliki. Fakta dari penelitian menunjukkan bahwa umur petani kawasan hutan rakyat yang ikut berpartisipasi dalam pengelolaan hutan rakyat sangat variatif mulai dari petani muda hingga petani berusia lanjut. Sebagai sebuah inovasi baru, pengembangan hutan rakyat diadopsi oleh petani dengan berbagai tingkatan umur.

Pendidikan formal dan non-formal tidak berkorelasi nyata pada taraf $\alpha \leq 5 \%$ dengan partisipasi petani dalam pengelolaan hutan rakyat. Hal ini menunjukkan bahwa pengetahuan dan ketrampilan yang dimiliki oleh petani tidak mempengaruhi tingkat partisipasi petani dalam pengelolaan hutan rakyat. Pengetahuan dan juga ketrampilan mengenai pengelolaan hutan yang dimiliki petani berasal dari nenek moyang terutama mengenai budidaya tanaman jeungjing dan tanaman pangan. Selain itu, pengetahuan dan ketrampilan juga diperoleh dari berbagai pelatihan. Namun tingkat pengetahuan dan ketrampilan yang dimiliki oleh petani tidak serta merta membuat mereka berpartisipasi dalam pengelolaan kawasan hutan rakyat. Petani menggunakan pengetahuan dan juga ketrampilannya untuk membuat persemaian tanaman hutan. Hasil dari penjualan bibit tanaman hutan ini kemudian akan dijadikan sebagai tambahan penghasilan bagi petani.

Pendidikan formal meskipun tidak menunjukkan hubungan nyata pada taraf $\alpha \leq$ $5 \%$ dengan tingkat partisipasi para petani dalam pengelolaan hutan rakyat namun menunjukkan adanya hubungan yang positif antara pendidikan formal dengan partisipasi dalam evaluasi pengelolaan hutan. Artinya pendidikan formal yang tinggi akan dapat membuat petani mampu untuk menilai pengelolaan hutan yang dilakukan. Petani mengetahui teori-teori tentang bagaimana teknik silvikultur yang tepat untuk tanaman hutannya. Namun demikian, penilaian yang dilakukan petani tidak membuatnya aktif berpartisipasi dalam pelaksanaan hutan rakyat karena berbekal pendidikan formal yang tinggi, mereka mempunyai banyak pilihan untuk memperoleh pekerjaan selain menjadi petani. Hal ini ditunjukkan dengan adanya hubungan negatif antara pendidikan formal dengan partisipasi petani dalam pelaksanaan hutan rakyat. Hal ini sejalan dengan penelitian yang telah dilakukan oleh Tologbonse et al. (2013) yang menyatakan bahwa semakin tinggi pendidikan formal petani maka cenderung akan menurunkan partisipasinya karena memiliki kesempatan untuk memperoleh pekerjaan lain dengan pendapatan yang lebih tinggi dibandingkan menjadi petani.

Pengalaman berusaha para tani hutan rakyat tidak berkorelasi nyata pada taraf $\alpha \leq 5 \%$ dengan partisipasi petani dalam pengelolaan kawasan hutan rakyat. Hal ini menunjukkan bahwa pengalaman berusaha tani hutan rakyat yang dimiliki petani tidak mempengaruhi tingkat partisipasi petani dalam pengelolaan kawasan hutan rakyat. Pengalaman yang dimiliki oleh petani hutan rakyat tergolong masih singkat yaitu 8 tahun, sedangkan umur tanaman kehutanan yang siap tebang adalah 4-7 tahun untuk jeungjing dan 7-12 tahun untuk mahoni. Hal ini menyebabkan petani belum merasakan manfaat yang nyata dari hutan rakyat untuk kehidupannya. Sesuai dengan pernyataan Ife (1995) bahwa masyarakat akan berpartisipasi dalam suatu kegiatan apabila kegiatan tersebut membawa perubahan yang lebih baik. Pengalaman mengelola hutan rakyat yang baru 8 tahun menyebabkan para petani hutan baru bisa memanen hasil tanamannya satu kali saja sehingga mereka belum dapat merasakan perbedaan manfaat yang bagi kehidupan petani.

Luas lahan berkorelasi sangat nyata pada taraf $\alpha \leq 1 \%$ dengan partisipasi petani dalam pengelolaan hutan rakyat yaitu partisipasi dalam pelaksanaan pengelolaan hutan rakyat dan memanfaatkan hasil dari hutan rakyat. Semakin luas lahan hutan rakyat yang dimiliki petani maka akan semakin tinggi pula partisipasi petani dalam pelaksanaan dan memanfaatkan hutan rakyat. Petani yang memiliki lahan luas akan terus mengembangkan hutan rakyatnya dengan melakukan teknik budidaya yang lebih baik sehingga mereka berharap hasil yang diberikan oleh hutan rakyat juga semakin tinggi. Petani dengan luas lahan hutan rakyat yang besar juga memiliki lahan pertanian yang ditanami dengan tanaman pangan sehingga mereka tidak lagi akan mengkonversi hutan rakyatnya menjadi lahan pertanian pangan.Hal ini disebabkan karena untuk memenuhi kebutuhan sehari-hari cukup dengan mengandalkan hasil dari pertaniannya. Berbeda dengan petani dengan luas 
lahan sempit, mereka banyak yang mengkonversi lahannya menjadi lahan pertanian pangan karena tidak ada alternatif lain untuk memenuhi kebutuhan sehari-hari yang tidak dapat mengandalkan hasil hutan rakyat yang jangka waktunya lama.

Tingkat pendapatan petani berkorelasi sangat nyata pada taraf $\alpha \leq 1 \%$ dengan partisipasi petani dalam pengelolaan hutan rakyat yaitu partisipasi dalam pelaksanaan pengelolaan hutan rakyat dan memanfaatkan hasil dari hutan rakyat. Semakin tinggi pendapatan yang diperoleh petani maka akan semakin tinggi partisipasi petani dalam pelaksanaan dan pemanfaatan hasil hutan rakyat. Pendapatan ekonomi petani yang tinggi menyebabkan mereka tidak terlalu mempersoalkan daur tanaman hutan yang panjang sehingga mereka akan terus mengembangkan hutan rakyatnya. Hutan rakyat dijadikan sebagai investasi jangka panjang karena pendapatan yang tinggi sudah mampu memenuhi kebutuhan sehari-hari petani. Manfaat yang mereka peroleh dari hutan rakyat bukan hanya bernilai ekonomi saja melainkan juga ekologi, yaitu adanya perbaikan lingkungan.

Luas lahan dan tingkat pendapatan berhubungan sangat nyata pada taraf $\alpha \leq 1 \%$. Tingkat pendapatan yang tinggi membuat petani mengusahakan hutan rakyat dengan luasan yang besar karena untuk memenuhi kebutuhan sehari-hari petani menggunakan sumber pendapatan yang tidak berasal dari hutan rakyat. Hutan rakyat dijadikan sebagai investasi jangka panjang. Hal inilah yang menyebabkan petani tetap mempertahankan hutan rakyatnya dengan luasan yang cukup besar. Jumlah tanggungan keluarga tidak berkorelasi nyata pada taraf $\alpha \leq 5 \%$ dengan partisipasi petani dalam pengelolaan hutan rakyat. Hal ini menunjukkan bahwa jumlah tanggungan keluarga yang dimiliki oleh para petani ternyata tidak mempengaruhi tingkat partisipasi petani dalam pengelolaan hutan rakyat. Hutan rakyat dijadikan sebagai tabungan oleh petani Desa Benteng sehingga untuk mencukupi kebutuhan sehari-hari petani harus mencari sumber penghasilan lainnya. Penghasilan ini diperoleh dengan cara bertani tanaman pangan, bekerja sebagai buruh bangunan, atau menjadi buruh migran yang akan memberikan penghasilan dalam jangka waktu cepat sehingga berapa pun jumlah tanggungan keluarga petani tidak akan berpengaruh pada partisipasi mereka dalam pengelolaan hutan rakyat.

Motivasi petani berkorelasi sangat nyata pada taraf $\alpha \leq 1 \%$ dengan partisipasi petani dalam pengelolaan hutan rakyat yaitu partisipasi dalam pelaksanaan pengelolaan hutan rakyat dan memanfaatkan hasil dari hutan rakyat. Hal ini menunjukkan bahwa semakin tinggi motivasi yang dimiliki petani maka akan semakin tin ggi partisipasi petani dalam pengelolaan hutan rakyat. Motivasi utama yang dimiliki oleh petani Desa Benteng dalam mengelola hutan rakyatnya adalah untuk meningkatkan pendapatan. Pendapatan yang tinggi akan diperoleh ketika hasil yang diberikan oleh hutan rakyat juga memiliki nilai jual yang tinggi. Tanaman hutan akan memiliki mutu yang baik jika petani menerapkan teknik silvikultur yang tepat bagi tanaman tersebut. Hal inilah yang mendorong petani hutan rakyat Desa Benteng merawat tanamannya dengan baik dengan harapan akan dapat memberikan manfaat yang tinggi terutama untuk meningkatkan pendapatan. Kapulaga memiliki harga jual yang tinggi sebagai bahan baku jamu. Manfaat yang diperoleh petani bukan hanya berasal dari tanaman kayu saja melainkan juga dari tanaman di bawah tegakan berupa Selain itu, petani juga merasakan bahwa hutan rakyat juga bermanfaat untuk memperbaiki lingkungan yang semakin hari semakin panas.

\section{Hubungan Faktor Eksternal dengan Partisipasi Petani dalam Pengelolaan Hutan Rakyat}

Faktor eksternal petani hutan rakyat yang diamati pada penelitian ini adalah penyuluhan bidang kehutanan, ketersediaan informasi, dan dukungan kelompok. Untuk mengetahui adanya hubungan antara faktor eksternal petani hutan rakyat dengan partisipasi dalam pengelolaan hutan rakyat digunakan uji Rank-Spearman. Hasil dari analisis disajikan pada Tabel 5. Faktor eksternal adalah faktor dari luar diri petani yang berhubungan dengan partisipasi petani dalam pengelolaan hutan rakyat di Desa Benteng.

Berdasarkan Tabel5terlihatbahwa penyuluhan kehutanan berkorelasi nyata pada taraf $\alpha \leq 5 \%$ dengan partisipasi petani dalam pengelolaan hutan rakyat yaitu partisipasi dalam pemanfaatan hasil hutan rakyat. Hal ini menunjukkan bahwa semakin tinggi penyuluhan kehutanan maka akan semakin tinggi partisipasi petani dalam memanfaatkan hasil dari hutan rakyat. Petani sangat membutuhkan penyuluh untuk membantu mereka dalam mengelola hutan rakyatnya. Fakta empirik di lapangan menunjukkan bahwa ketika kegiatan penyuluhan dilakukan secara intensif pada awal pembangunan hutan rakyat tahun 2005, partisipasi petani sangat tinggi bahkan beberapa 
petani telah mengkonversi lahan pertaniannya menjadi hutan rakyat. Ketika kegiatan penyuluhan makin berkurang maka partisipasi petani juga menurun. Hal ini menunjukkan bahwa petani masih sangat membutuhkan berbagai kegiatan penyuluhan kehutanan untuk membantu mereka dalam mengelola hutan rakyat.

Sebagian besar petani hutan rakyat di Desa Benteng selama ini hanya sekedar memanfaatkan hasil hutan rakyat yang berupa kayu dan sedikit tanaman pertanian. Padahal masih banyak manfaat yang dapat diperoleh para petani dari hutan rakyat. Penyuluhan kehutanan dapat membantu petani untuk memperoleh tambahan manfaat dari kawasan hutan rakyat. Kegiatan penyuluhan dapat dilakukan dengan materi-materi mengenai diversifikasi tanaman hutan rakyat. Tanaman tumpang sari yang ditanam setelah tanaman kayu berusia 3-4 tahun dapat dipilih tanaman yang toleran terhadap naungan sehingga sepanjang daur,lahan dibawahtegakan akan dapat terus dimanfaatkan. Tujuan dari adanya kegiatan penyuluhan adalah melakukan perubahan perilaku pada diri klien sesuai dengan rencana yaitu berubah ke arah yang lebih baik. Penyuluhan kehutanan juga dapat memberikan pengetahuan dan ketrampilan kepada warga masyarakat untuk melakukan kegiatan pemangkasan dan penjarangan.Hasil pemangkasan dan penjarangan dapat digunakan oleh petani sebagai kayu bakar sehingga dapat mengurangi pengeluaran petani atau dapat dijual sehingga petani dapat memperoleh tambahan penghasilan.

Penyuluhan kehutanan juga dapat memberikan pemahaman kepada petani Desa Benteng bahwa manfaat yang akan diperoleh dari hutan rakyat bukan hanya yang bersifat ekonomis namun juga perbaikan lingkungan yang akan berdampak pada semua warga Desa Benteng khususnya dan masyarakat pada umumnya. Salah satu keuntungan ekologis yang akan diperoleh masyarakat adalah perbaikan lingkungan sehingga Desa Benteng tidak terlalu panas. Selain itu, dalam jangka panjang akan muncul sumber-sumber air yang dapat dimanfaatkan untuk mengairi sawah di Desa Benteng yang sebagian besar hanya dapat mengandalkan curah hujan. Sesuai dengan penelitian Djamhuri (2008) yang dilakukan di kabupaten Gunung Kidul DIY, bahwa manfaat dari hutan rakyat adalah adanya perbaikan iklim mikro yang tidak hanya bermanfaat bagi petani hutan rakyat namun juga bermanfaat bagi masyarakat pada umumnya.

Ketersediaan informasi mengenai hutan rakyat tidak berkorelasinyata pada taraf $\alpha \leq 5 \%$ dengan partisipasi petani dalam pengelolaan kawasan hutan rakyat. Hal ini menunjukkan bahwa banyaknya informasi yang diperoleh petanitidakmempengaruhitingkatpartisipasipetani dalam pengelolaan hutan rakyat. Informasi hutan rakyat yang diperoleh petani tidak membuat petani kemudian terlibat aktif dalam pengelolaan kawasan hutan rakyat. Menurut Rogers (1995), meskipun seseorang mengetahui akan suatu inovasi namun bukan berarti dia akan menerapkan inovasi tersebut. Hutan rakyat merupakan sebuah inovasi bagi petani di Desa Benteng. Petani memperoleh banyak informasi mengenai hutan rakyat dari berbagai sumber baik media, penyuluh, kelompok, maupun dari sesama petani namun informasi ini tidak membuat petani Desa Benteng kemudian berpartisipasi aktif dalam pengelolaan hutan rakyat. Banyak atau sedikitnya informasi yang diperoleh petani tidak mempengaruhi partisipasi mereka dalam pengelolaan hutan rakyat.

Dukungan kelompok berkorelasi nyata pada taraf $\alpha \leq 5 \%$ dengan partisipasi petanidalampengelolaan hutan rakyat yaitu partisipasi dalam pemanfaatan hasil hutan rakyat. Hal ini menunjukkan bahwa semakin tinggi dukungan kelompok maka akan semakin tinggi partisipasi petani dalam memanfaatkan hasil dari hutan rakyat. Petani hutan Desa Benteng tergabung dalam Kelompok Tani Asih. Melalui kelompok ini maka inovasi hutan rakyat disosialisasikan kepada masyarakat pada tahun 2005. Melalui kelompok juga telah dilakukan koordinasi terkait pembagian bibit dan bantuan pupuk yang diberikan kepada petani untuk membangun hutan rakyat. Kegiatan penyuluhan kehutanan dilakukan pada saat ada pertemuan rutin kelompok sehingga terjadi pertukaran pengetahuan dan juga pengalaman baik antara penyuluh dan petani atau antara petani dengan petani.

Peningkatanpengetahuandanjugaketrampilan para petani diperoleh melalui interaksi yang terjadi di dalam kelompok. Berbagai informasi dapat diperoleh petani dari kelompok termasuk berbagai fasilitas yang diberikan oleh pemerintah baik pemda maupun pusat. Sebagian besar petani hutan rakyat di Desa Benteng selama ini hanya sekedar memanfaatkan hasil hutan rakyat yang berupa kayu dan sedikit tanaman pertanian. Pertemuan rutin yang dilakukan oleh kelompok setiap bulan yaitu pada Minggu II dijadikan sebagai ajang untuk membicarakan berbagai persoalan yang dihadapi petani dalam mengelola hutan rakyat. Informasi inilah yang digunakan oleh petani untuk meningkatkan pengelolaan hutan rakyatnya agar diperoleh manfaat yang lebih tinggi dari hutan rakyat. 


\section{Kesimpulan}

Partisipasi petani hutan di Desa Benteng dalam pengelolaan hutan rakyat tergolong rendah dalam setiap tingkatan partisipasi mulai dari pelaksanaan hingga evaluasi. Faktor-faktor yang berhubungan nyata dengan partisipasi petani dalam pengelolaan hutan adalah luas lahan, pendapatan, motivasi, penyuluhan kehutanan, dan juga dukungan kelompok. Partisipasi para petani dalam pengelolaan kawasan hutan rakyat sangat penting dalam pembangunan hutan rakyat. Petani akan berpartisipasi ketika hutan rakyat mampu memberikan manfaat bagi kehidupannya baik manfaat ekonomi, ekologi, maupun manfaat sosial. Kegiatan penyuluhan masih sangat diperlukan oleh petani untuk mengembangkan hutan rakyat di Desa Benteng. Intensifikasi kegiatan penyuluhan harus lebih ditingkatkan lagi karena masih ada banyak persoalan yang dihadapi oleh petani dalam mengembangkan hutan rakyat. Kegiatan penyuluhan harus dilakukan secara berkesinambungan, yaitu melibatkan para pihak yang terkait untuk memfasilitasi masyarakat khususnya petani agar mampu lebih berdaya. Kementerian Kehutanan dan pemda (dinas kehutanan dan badan penyuluhan) telah bahu membahu memfasilitasi petani dalam mengembangkan hutan rakyat.

Kemenhut menyusun regulasi yang dapat mendorong masyarakat untuk mengembangkan hutan rakyat, misalnya dengan menyederhanakan pasal peraturan mengenai pengangkutan dan penjualan kayu rakyat. Pemerintah daerah (Pemda) melalui penyuluhnya terus mendampingi para petani yang sudah dianggap mampu untuk dilepas karena dianggap memiliki daya. Jumlah penyuluh kehutanan yang sangat terbatas dapat disikapi dengan melakukan kaderisasi kepada petanipetani maju (petani inovatif) agar mampu menjadi penyuluh swadaya di desanya agar kegiatan penyuluhan dapat terus berjalan dengan baik meskipin jumlah penyuluh PNS yang terbatas. Dukungan kelompok tani sangat diperlukan oleh petani hutan rakyat untuk mengembangkan hutan rakyatnya. Oleh karena itu, kelompok harus mampu menciptakan jejaring kerja dengan para pihak guna mendukung pembangunan hutan rakyat di Desa Benteng. Penyuluh kehutanan harus mampu memfasilitasi kelompok agar mampu membangunjejaring terutama dengan lembagakeuangan dan pemasaran sehingga petani tidak kesulitan untuk memperoleh dukungan modal dan memasarkan hasil hutannya. Petani perlu dilibatkan dalam pembangunan hutan rakyat mulai dari perencanaan hingga evaluasi sehingga ada rasa memiliki dan turut bertanggung jawab atas hasil yang diperoleh.

\section{Daftar Pustaka}

Aziz N. 1995. Hubungan Karakteristik Petani dengan Aktivitas Komunikasi Terhadap Tingkat Pengetahuan Mereka Tentang Dampak Perladangan Berpindah dan Pola Pertanian Menetap [tesis]. Bogor (ID): Institut Pertanian Bogor.

BRIK [Badan Revitalisasi Industri Kehutanan]. 2010. Hutan Rakyat: Peran yang Makin Nyata. [Internet]. [dapat diunduh dari: http://www. brikonline.co.html].

CIFOR [Center for International Forestry Research]. 2005. Sintesis: Restrukturisasi Industri Kehutanan dan Skenario Masa Depan. 6. Harapan ke Depan: Revitalisasi Industri (s/d tahun 2020). [Internet]. [dapat diunduh dari: http://www.cifor.cgiar.org

Darusman D. 2002. Hutan Rakyat: Pengembangan Strategis Kehutanan. Di dalam: Pembenahan Kehutanan Indonesia. Bogor (ID): Laboratorium Politik Ekonomi dan Sosial Yayasan Dani Hanidah.

Davis K. 1967, Human Relations at Work: The Dynamic of Organization Behaviour. New York: McGraw-Hill Book Company.

Diarto, Boedi H, Suryoko S. Partisipasi Mayarakat dalam Pengelolaan Lingkungan Kawasan Hutan Mangrove Tugurejo di Kota Semarang. Di dalam Jurnal Ilmu Lingkungan 10.

Djamhuri TL. 2008. Community Participation in a Social Forestry Program in Central Java, Indonesia: The Effect of Incentive Strucuture and Social Capital. Di dalam Journal of Agroforest Syst 74.

Gupte M. 2004. Participation in a Gendered Environement: The Case of Community Forestry in India. Di dalam Journal of Human Ecology 32. [Internet]. [dapat diunduh dari: http:/search. proquest.com].

Hudiyani I. 2010. Kelembagaan Penyuluhan Partisipatif dalam Pengelolaan Hutan Rakyat (Studi Kasus Komunitas Petani Sertifikasi Percabaan Dusun Pagersengon Kelurahan Selopuro Kecamatan Batuwarno Kabupaten Wonogiri Provinsi Jawa 
Jurnal Penyuluhan, September 2013 Vol. 9 No. 2

Tengah)

Ife J. 1995. Community Development: Creating Community Alternatives - Vision,Anallysis and Practice: Australia: Longman Australia Pty. Ltd.

Kemenhut [Kementerian Kehutanan]. 2010.

Rencana Strategis 2010-2014. Jakarta (ID): Kementerian Kehutanan.

Rogers Everett M. 1995. Diffusion of Innovations.

New York: The Free Press.
Tologbonse et al. 2013. Factors Influencing Women in Women in Agriculture (WIA) Programme of Kaduna Sate Agricultural Development Project Nigeria. Di dalam International Journal of Agricultural Economics and Extension. [Internet]. [dapat diunduh dari: http://www. internationalscholarsjournals.org]. 